\title{
UDC 621.791.052
}

\section{IMPROVEMENT OF PRT-9 CONSTRUCTIVE SYSTEM ON THE BASIS OF FRAME ELEMENTS STRENGTH BALANCE}

\author{
Taras Dovbush; Nadia Khomyk; Hanna Tson; Anatoliy Dovbush
}

\author{
Ternopil Ivan Puluj National Technical University, Ternopil, Ukraine
}

\begin{abstract}
Summary. Analytical and experimental investigations of the most loaded elements of the base frame of PRT-9 solid organic fertilizer spreader are carried out in this paper. The residual operation life of the central beam of the paired Z-shaped profile, as well as the lateral spars of the Z-shaped cross section are determined. According to the results of studies, it was found that the residual operation life of these system elements differ significantly. In order to achieve strength uniformity of the main frame elements, it is decided to weaken the central beam by replacing the paired Z-shaped profile with a thin-walled tube of rectangular cross-section and strengthen the lateral spars by replacing Z-shaped profile with a channel profile with the same height.
\end{abstract}

Key words: constructive system, stress, operation life.

Statement of the problem. The basic model of the structural system of PRT-9 solid fertilizer spreader is not rationally designed in terms of its single parts durability. The residual operation life of the central spar is $T_{2} / T_{1}=11630 / 1771=6,57$ times greater than the operation life of the lateral spars. This is a significant disadvantage.

Analysis of the available investigation results. Analytical and experimental investigations of the stress-strained state (hereinafter SST) and methods for the estimation of the operation life of agricultural machinery structural systems are reflected in numerous scientific papers, particularly in paper [1]. Investigations of SST and calculation of the residual life of solid organic fertilizer sprayer are carried out in papers [2], [3]. Analytical investigations aimed at the determination of the critical crack length of the channels and thin-walled pipes with rectangular cross-sections are given in [4].

Objective of the paper is to provide the same operation life of the central beam and lateral spars of the structural system of PRT-9 solid organic fertilizer spreader.

Statement of the task is to replace the main profiles of PRT-9 main frame crosssections in order to equalize the stress-strain state in them.

Investigation results. The task to ensure the rational stresses redistribution in the structural elements is the basis of the main recommendations for improving the carrier system of PRT-9 fertilizer spreader. In order to reduce stresses in these cross-sections and relatively to increase the residual operation life of the lateral spars it is proposed to replace Z-shaped profile by channel $200 \times 100 \times 6$, GOST $8278-83$.

It is also recommended to replace the understressed central beam of the paired Z-shaped profile by thin-walled pipe with rectangular cross-section 200x100x5, GOST 30245-2003.

Such combination of profiles makes it possible to balance the stress state of the structural system elements. The formed closed profile of the central beam increases its corrosion resistance as organic fertilizers do not get into the middle of the profile and after the profile replacement there is no need in using the additional elements and welding for frame formation and this increases the entire structure technological effectiveness. 
For manufacturing two longitudinal spars of the spreader frame it is proposed to use cold-formed channels D200x100x6, GOST 8278-83 and for central beam - formed closed profile 200x100x5, GOST 30245-2003. The application of the developed recommendations provides the reduction of the structure metal consumption by $40 \mathrm{~kg}$. Useful model patent \#92328 is acquired for the proposed solution [5].

It is recommended to replace the lateral spars of the improved structural system of PRT9 fertilizer spreader by bend channel.

For channel rolling of the standard series from \#10 to \#24 the array of correction functions values (for $0<\varepsilon<0,8$ ) can be approximated by generalized curve (the first and the second stage of crack growth) [4]:

$$
\begin{aligned}
F_{12}(\varepsilon)= & 1,036+3,189 \varepsilon+4,481 \varepsilon^{2}-173,864 \varepsilon^{3}+309,338 \varepsilon^{4}+10999,103 \varepsilon^{5}- \\
& -80602,932 \varepsilon^{6}+232137,410 \varepsilon^{7}-306266,279 \varepsilon^{8}+154375,438 \varepsilon^{9} .
\end{aligned}
$$

where $\varepsilon_{1}$ is the ratio of the crack area to the gross cross-section area of the channel.

Using dependence (1) at average $62 \mathrm{MPa}$ operating stresses we construct the graph for the dependence of stress intensity factor (hereinafter SIF) on the crack development in bend channel (Fig. 1). From the graph we determine the critical crack length at which fracture occurs $l_{K_{12}}=0,1395 \mathrm{~m}$.

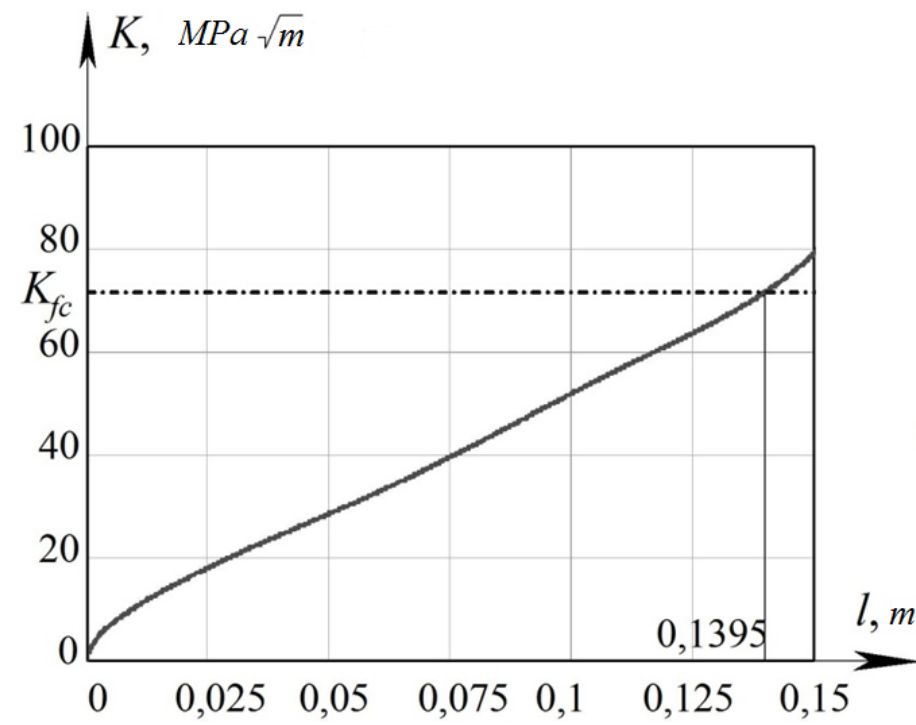

a)

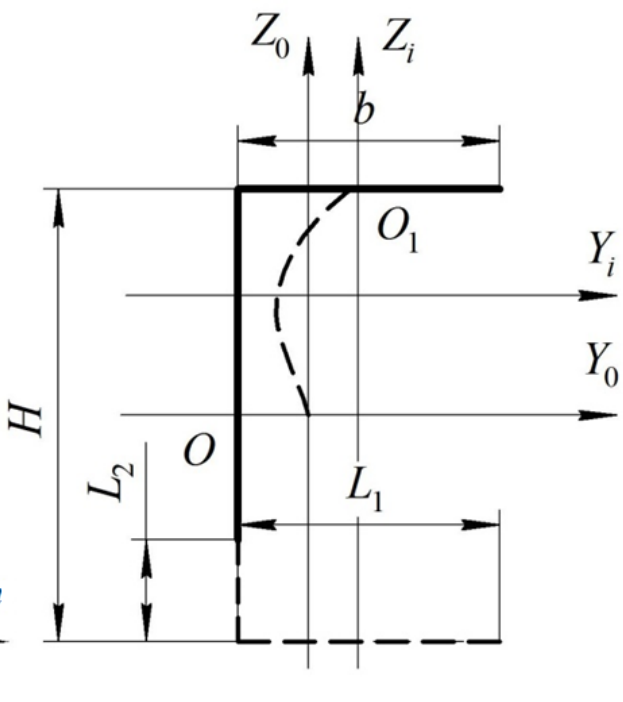

b)

Figure 1. Graphical interpretation of crack development cross-sections made of bent channel:

a) determination of the critical crack length $K_{f c}=71,5 \mathrm{MPa} \sqrt{\mathrm{m}}$;

б) the crack development in cross-section $l_{K_{12}}=L_{1}+L_{2}=0,1395 \mathrm{~m}$.

Then we determine the residual operation life of the improved lateral spar of PRT-9 frame made of bend channel (Fig. 2), $T_{12}=2899 \mathrm{~h}$.

As the result of profiles replacement, the durability of lateral spars increased by $T_{12} / T_{1}=$ $2899 / 1771=1.64$ times. 


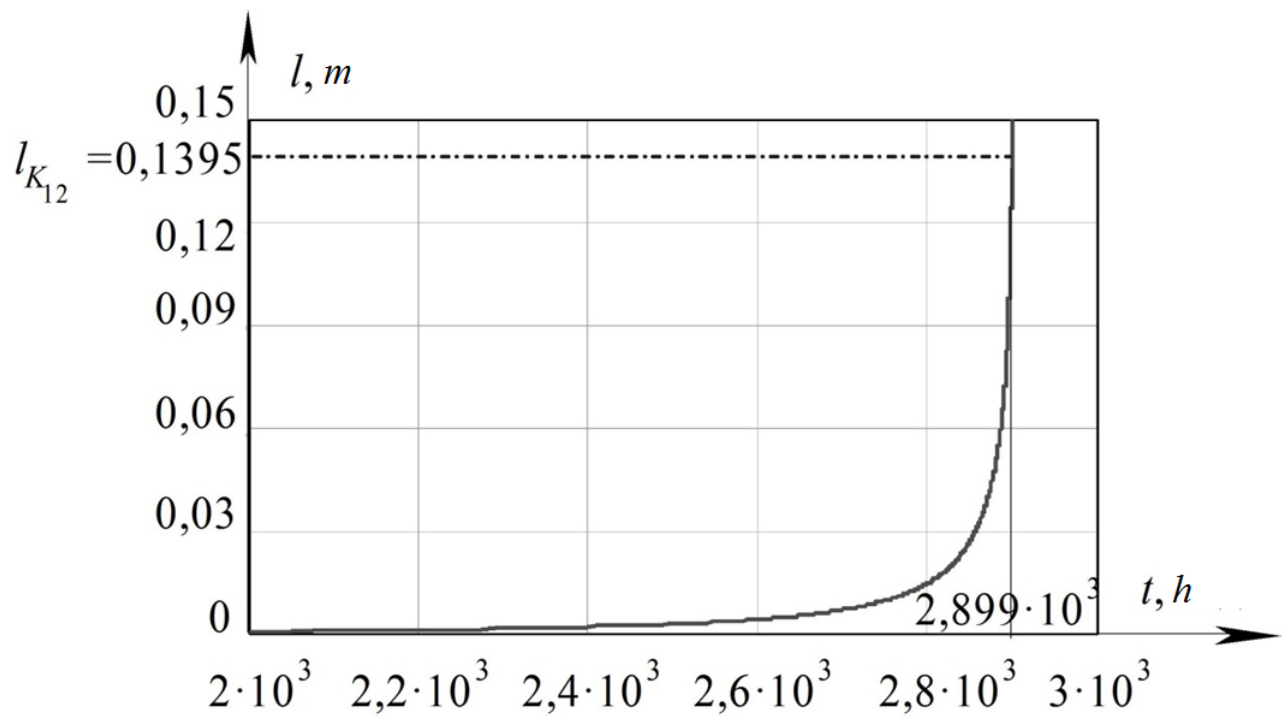

Figure 2. Residual operation life of the improved lateral spar of PRT-9 frame

It is recommended to replace the central beam of PRT-9 fertilizer spreader structural system made of paired Z-shaped profiles by box profile (Fig. 3).

SIF value at the crack tip of the bend-welded thin-walled element of the box profile is determined by the following formula [4]:

$$
K_{I}=\sigma \sqrt{\pi L} \cdot F(\varepsilon)
$$

where $\sigma$ are normal stresses in defect-free cross-section of the closed profile, $\mathrm{MPa}$;

$L$ is total crack length, $L=L_{1}+L_{2}, L_{1}=L_{2}, L=\varepsilon(b+H-2 t)$, m;

$F(\varepsilon)$ is correction function.

For closed box profiles the array of correction functions values can be approximated by generalized function [4]:

$$
\begin{aligned}
F_{22}(\varepsilon) & =0,793+0,186 \varepsilon+3,839 \varepsilon^{2}-20,474 \varepsilon^{3}+ \\
& +55,021 \varepsilon^{4}-67,186 \varepsilon^{5}+31,823 \varepsilon^{6} .
\end{aligned}
$$

For the given cross-section see Fig. 3 under average $52 \mathrm{MPa}$ operation stresses we determine the critical crack length. Then we construct SIF dependence on crack development in box cross-section, ${ }^{K_{22}}=0,2975 \mathrm{~m}$ (Fig. 4). 


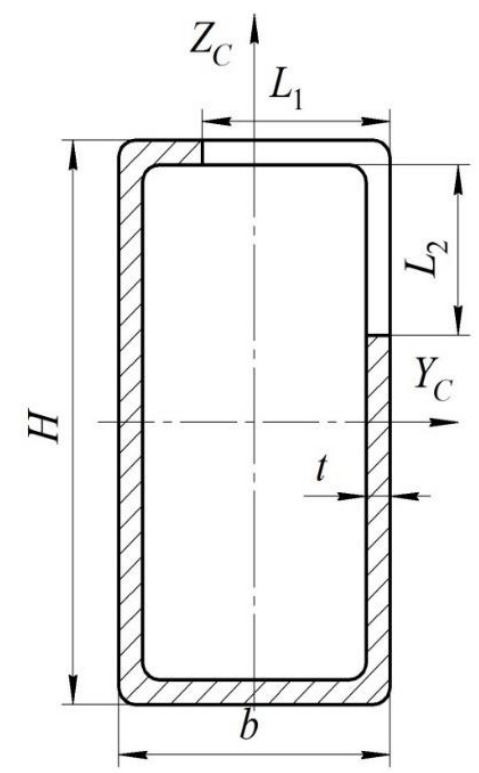

Figure 3. Development of angular crack in closed box profile

While investigating the residual operation life of the central beam of PRT-9 frame under certain critical crack length, we obtain $T_{22}=4663$ h (Fig. 5).

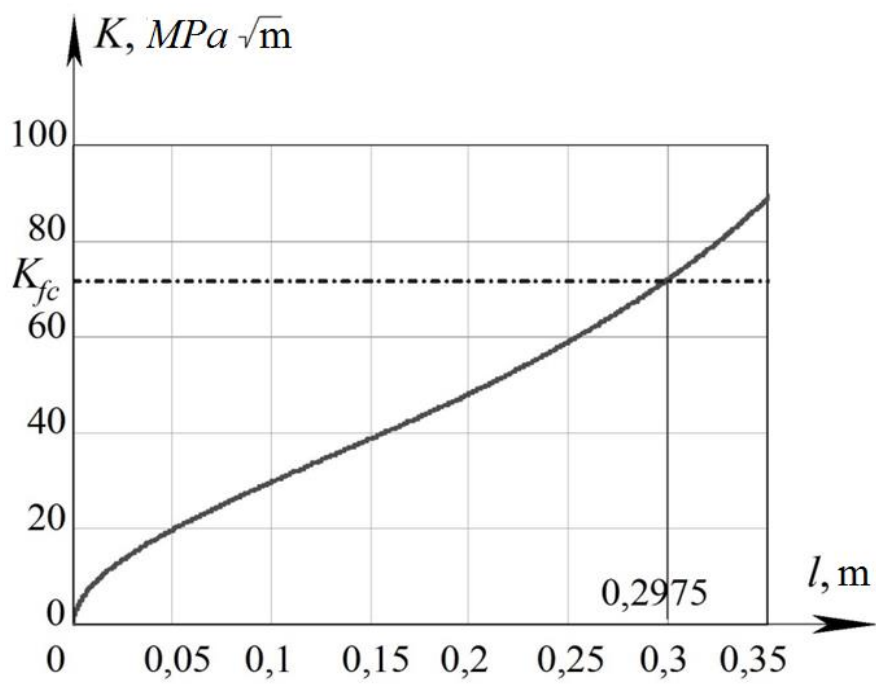

a)

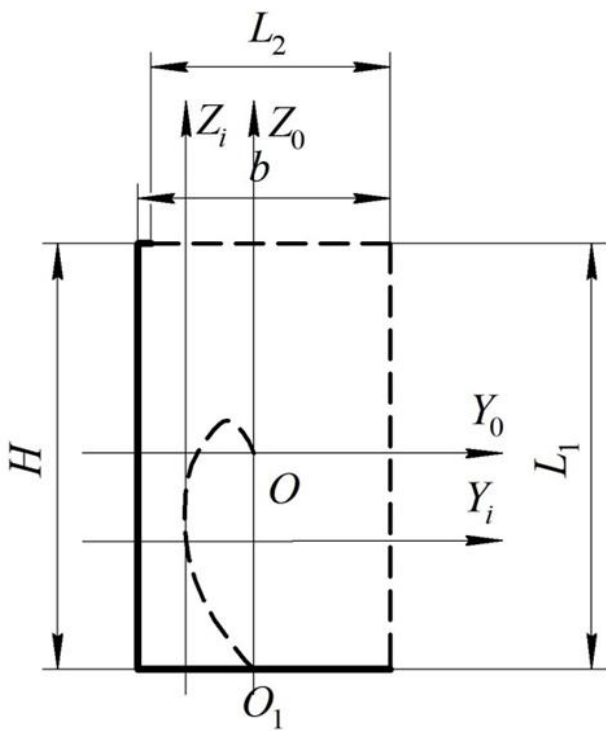

b)

Figure 4. Graphical interpretation of crack development in closed cross section:

a) determination of critical crack length $K_{f_{c}}=71,5 \mathrm{MPa} \sqrt{\mathrm{m}}$;

b) crack development in cross section $l_{K_{22}}=L_{1}+L_{2}=0,2975 \mathrm{~m}$.

As the result of the carried out investigation of PRT-9 frame the durability of the central beam of PRT- 9 frame decreased by $T_{2} / T_{22}=11630 / 4663=2,49$ times, making it possible to bring into alignment the overall structural system durability. 


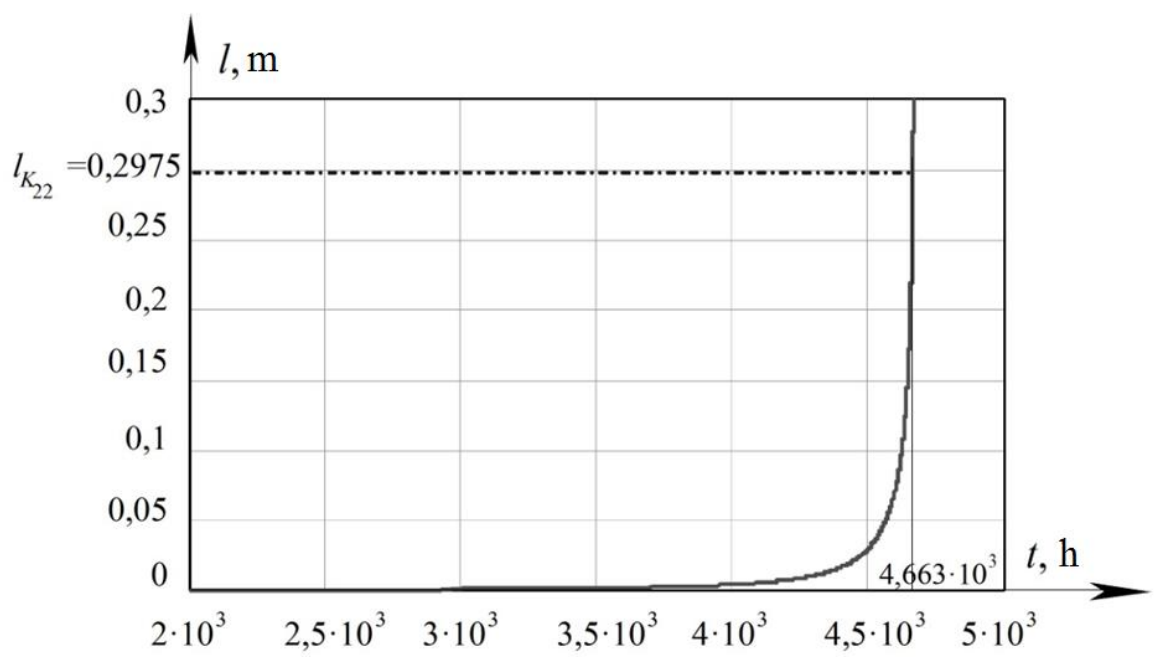

Figure 5. The residual operation life of the improved central beam

The results of the investigation of the residual operation life of the basic and improved spreader structural system are summarized in Table 1.

Table 1

Comparison of the level of stress and durability in the most loaded sections of PRT-9 spreader carrier system

\begin{tabular}{|c|c|c|c|c|c|c|}
\hline \multirow[b]{2}{*}{ 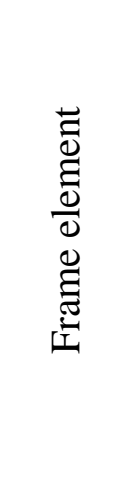 } & \multicolumn{3}{|c|}{ Basic modification } & \multicolumn{3}{|c|}{ Improved modification } \\
\hline & 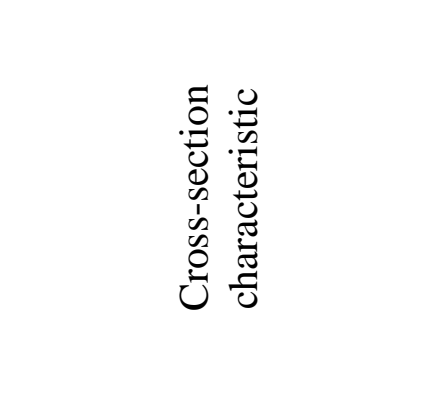 & 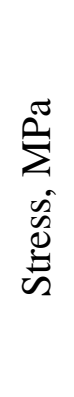 & 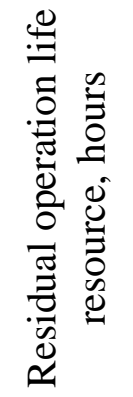 & 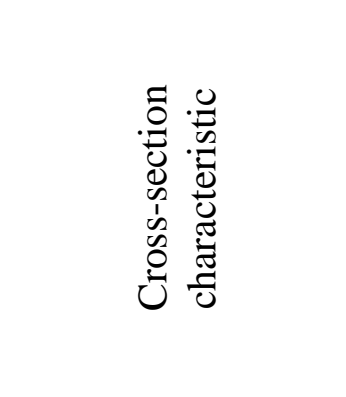 & 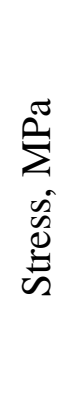 & 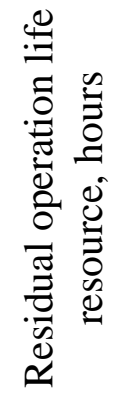 \\
\hline Spar & $\begin{array}{l}\text { Z-shaped profile, } \\
200 \times 87 \times 6\end{array}$ & 66 & 1771 & $\begin{array}{l}\text { Cold-bend channel } \\
200 \times 100 \times 6\end{array}$ & 62 & 2899 \\
\hline $\begin{array}{l}\text { Central } \\
\text { beam }\end{array}$ & $\begin{array}{l}\text { Paired Z-shaped profile, } \\
\qquad 200 \times 87 \times 6\end{array}$ & 29 & 11630 & $\begin{array}{l}\text { Square pipe } \\
200 \times 100 \times 5\end{array}$ & 52 & 4663 \\
\hline
\end{tabular}

Conclusions. The spreader structural system is improved by replacing the profiles of carrier elements. The results of the proposed replacement: the resource of the spars operation life is increased, but that of the central beam is decreased. Hence, the operation life resource of the central beam of the spreader frame relatively to the operation life resource for lateral spars is 1.61 times.

\section{References}

1. Popovych P., Poberezhny L., Shevchuk O., Murovanyi I., Dovbush T., Koval Yu., Hrytsuliak H. Evaluation of strength of carrying metal structures of trailers. Journal of Achievements in Materials and Manufacturing Engineering. 2020. Vol. 100. No. 2. P. 58-69. DOI: https://doi.org/10.5604/01.3001.0014.3345 
2. Dovbush T. Khomuk N., Dovbush A., Rubinets N. Mathematical model of boundary crack propagation at bending of symmetric thin-walled flanks. Scientific Journal of TNTU. Ternopil TNTU, 2017. No. 2 (86). P. 67-75.

3. Dovbush T., Khomyk N., Dovbush A., Dunets B. Evaluation technique of frame residual operational life. Scientific Journal of TNTU (Tern.). 2019. Vol. 93. No. 1. P. 61-69. DOI: https://doi.org/10.33108/visnyk_tntu2019.01.061

4. PIdgurskiy M., StashkIv M. Metodi viznachennya KIN dlya defektnih elementIv vIdkritogo profllyu. Visnik TDTU. 2006. Tom 11. No. 3. P. 92-108.

5. Popovich P., Bably A., StashkIv M., Dovbush T. Pat. Ukrayini na korisnu model № 92328, MPKAJ1C 15/00. Rama rozkidacha tverdih organIchnih dobriv / vid 11.08.2014 r. zayavl. 18.03.2014 r.; opubl. 11.08.2014 r.; Byul. № 152014 r.

\title{
Список використаної літератури
}

1. Popovych P., Poberezhny L., Shevchuk O., Murovanyi I., Dovbush T., Koval Yu., Hrytsuliak H. Evaluation of strength of carrying metal structures of trailers. Journal of Achievements in Materials and Manufacturing Engineering. 2020. Vol. 100. No. 2. P. 58-69. DOI: https://doi.org/10.5604/01.3001.0014.3345

2. Dovbush T. Khomuk N., Dovbush A., Rubinets N. Mathematical model of boundary crack propagation at bending of symmetric thin-walled flanks. Scientific Journal of TNTU. Ternopil TNTU, 2017. No. 2 (86). P. 67-75.

3. Dovbush T., Khomyk N., Dovbush A., Dunets B. Evaluation technique of frame residual operational life. Scientific Journal of TNTU (Tern.). 2019. Vol. 93. No. 1. P. 61-69. DOI: https://doi.org/10.33108/visnyk_tntu2019.01.061

4. Підгурський М., Сташків М. Методи визначення КІН для дефектних елементів відкритого профілю. Вісник ТДТУ. 2006. Том 11. № 3. С. 92-108.

5. Пат. України на корисну модель № 92328, МПКАЈ1С 15/00. Рама розкидача твердих органічних добрив від 11.08.2014 р.; заявл. 18.03.2014 р.; опубл. 11.08.2014 р. Бюл. № 152014 р.

\section{УДК 621.791.052}

\section{УДОСКОНАЛЕННЯ КОНСТРУКТИВНОЇ СИСТЕМИ ПРТ-9 НА ОСНОВІ РІВНОМЦЦОСТІ ЕЛЕМЕНТІВ РАМИ}

\author{
Тарас Довбуш; Надія Хомик; Ганна Цьонь; Анатолій Довбуш
}

\author{
Тернопільський начіональний технічний університет імені Івана Пулюя, \\ Тернопіль, Україна
}

\begin{abstract}
Резюме. Конструктивна система будь-якої машини, в тому числі й сільськогосподарської, складається з великої кількості різних металічних елементів відкритого та закритого поперечного перетинів, які з'єднані зварюванням. Виконано аналітично-експериментальні дослідження найбільш навантажених елементів базової рами розкидача твердих органічних добрив ПРТ-9. Визначено залишковий ресурс роботи иентральної балки спареного Z-подібного профілю, а також бокових лонжеронів Z-подібного поперечного перетину. За результатами досліджень встановлено, щзо залишкові ресурси роботи ичи елементів системи суттєво відрізняються. Це - результат значного напруженодеформівного стану бокових лонжеронів і помітного недовантаження центральної балки, щчо є основним недоліком конструктивної системи. Для досягнення рівноміцності основних елементів рами вирішено послабити центральну балку заміною спареного Z-подібного профілю тонкостінною трубою прямокутного поперечного перетину й посилити бокові лонжерони, замінивщи Z-подібний профіль на швелерний такої ж висоти. Для реконструйованої рами досліджено ї̈ напружено-деформівний стан на основі визначення критичних довжин тріщин. Також визначено залишковий ресурс роботи кожного із замінених елементів конструктивної системи. За результатами досліджень встановлено, щзо залишковий ресурс роботи несучих елементів рами вирівнявся. Наведено порівняльний аналіз досліджень залишкового ресурсу роботи базової та удосконаленої конструктивних систем розкидача твердих органічних добрив.

Ключові слова: конструктивна система, напруження, ресурс роботи.
\end{abstract}

